\title{
Diel cycles of heterotrophic bacterioplankton abundance and production in the ocean surface waters
}

\author{
Fuh-Kwo Shiah* \\ PO Box 23-13, Institute of Oceanography, National Taiwan University, Taipei, Taiwan, ROC
}

\begin{abstract}
To examine the magnitude of phytoplankton-bacterial coupling in low productivity areas, diel changes of bacterial abundance and production as well as primary production (PP) in the oligotrophic Kuroshio surface waters were investigated by on deck carboy incubation and consecutive hydrocast sampling. Both methods yielded similar results. Cell counts varied $<13 \%$ in 1 diel cycle, while thymidine (TdR) incorporation rates and $\mathrm{TdR}$ incorporation per cell ( $\mathrm{TdR}$ cell ${ }^{-1}$ ) varied 2- to 5-fold with higher values appearing at night. Such opposing trends between the bacterial rate parameters and PP were consistent over different locations and months. When incubated under an artificial light source, the TdR cell ${ }^{-1}$ in whole water samples were negatively correlated with light intensity and PP. In nutrient enrichment experiments, the addition of labile organic carbon (glucose) had no effect on bacterial growth in noon and midnight samples. Values of the $\mathrm{TdR}$ cell ${ }^{-1}$ in midnight samples increased about $70 \%$ when the inorganic nutrient mixture $\left(\mathrm{NH}_{4}{ }^{+}\right.$and $\left.\mathrm{PO}_{4}{ }^{-3}\right)$ was added; however, such addition did not enhance the $\mathrm{TdR} \mathrm{cell}^{-1}$ in noon samples. This study demonstrates that the diel pattern of bacterial growth in the ocean surface water is opposite to that of phytoplankton. UV radiation is not required in driving such a variation since UV was excluded in the experimental set-up. There seems to be no simple explanation for the phenomenon reported by this study. Other potential factors, such as inorganic nutrient, organic substrate supply rates and bacterivory, all might play roles in affecting the bacterial diel cycle.
\end{abstract}

KEY WORDS: Bacteria - Oligotrophic $\cdot$ Kuroshio $\cdot$ Growth rate $\cdot$ Inorganic nutrients $\cdot$ Dissolved organic carbon

\section{INTRODUCTION}

Heterotrophic bacterioplankton are the organisms mostly responsible for the consumption of dissolved organic substance in the aquatic ecosystem. In the open ocean, the sources of organic supply for bacteria may come from extracellular dissolved organic carbon (EDOC) released from algae, zooplankton sloppy feeding, excretion from other organisms, release from dead particles, and virus-induced lysis (see Ducklow \& Carlson 1992, Fuhrman 1992 for review). Among them, algal EDOC is considered the primary source of organic substrate for bacterial growth. This is supported by much of the literature which indicate that the diel cycles of phytoplankton production and bacte-

•E-mail: frank@odb03.gcc.ntu.edu.tw rial activity are closely coupled (for review see Coffin et al. 1993). Although diel studies on the coupling of phytoplankton and bacteria activities have been performed in freshwater, estuaries and coastal waters, similar studies in oligotrophic ocean waters are rare.

In oligotrophic environments where substrate supply rates are low, one may intuitively suspect that the bacterial diel variation probably would be stronger and more tightly coupled with phytoplankton activities than that in higher productivity regimes (e.g. Fuhrman et al. 1985), and that the variation might change spatially and temporally. In addition to substrate supply rate, other environmental factors such as bacterivory (Wikner et al. 1990), inorganic nutrient supply (Contner et al. 1997, Shiah et al. 1998; see also Obernosterer \& Herndl 1995, Pomeroy et al. 1995 for review) and ultraviolet radiation (Herndl et al. 1997, Jeffrey et al. 
1996) might also affect bacterial abundance and growth rate at diurnal scale.

To examine the magnitude of phytoplankton-bacteria coupling in low productivity areas, diel changes of bacterial and phytoplankton activities were additionally investigated in the oligotrophic Kuroshio waters by on deck carboy incubations and consecutive hydrocast sampling. Artificial light manipulation and nutrient enrichment experiments were also conducted on board to examine bacterial responses to photosynthetic available radiance (PAR) and the addition of inorganic (ammonium and phosphate) as well as organic (glucose) substrate, respectively.

\section{MATERIALS AND METHODS}

This series of studies was performed at the 3 stations along the main stream of the oligotrophic Kuroshio waters east and northeast of Taiwan (Fig. 1) in May, July and August 1996 (Table 1). Stn 34 was visited twice on the July and August cruises. Seawater was collected from a SeaBird CTD-General Oceanic Rosette assembly with 20 I Go-Flo bottles. Daily light intensity was measured with a PAR sensor (QSP200L; Biospherical).

Diel study. Freshly collected surface water $(<0.5 \mathrm{~m})$ was held in 3 transparent 20 I polycarbonate (PC) carboys (Nalgene) and incubated on deck at in situ light intensity with running seawater. Two of the carboys were used for diel sampling, while the third carboy was reserved for manipulation experiments (see below). Bacterial and phytoplankton activities in the third carboy were checked at irregular intervals and compared with those in the other 2 carboys for diel study; no significant differences were found among them (see also 'Results'). Bacterial and phytoplankton production were measured every 3 to $4 \mathrm{~h}$. In the May

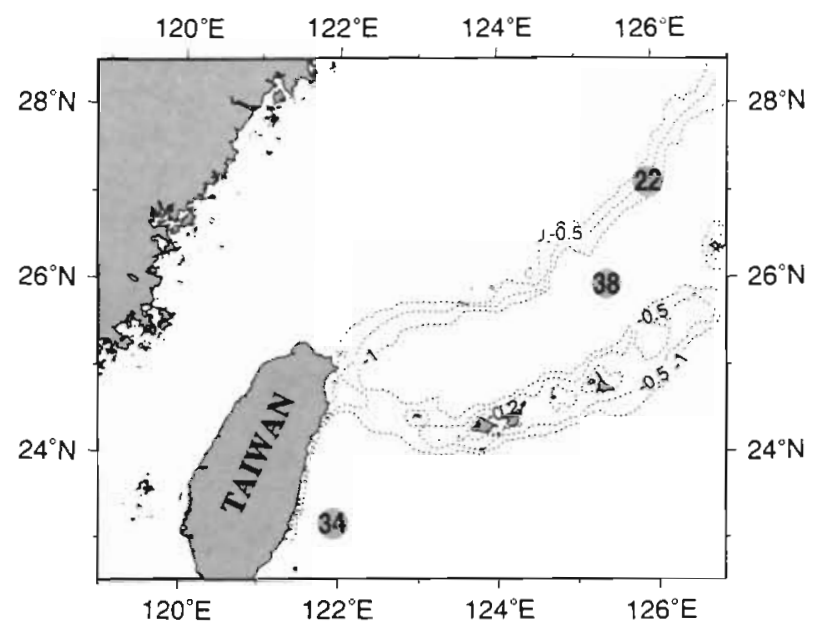

Fig. 1. Map of the southern East China Sea showing sampling stations. Dashed lines indicate bottom depths in units of $\mathrm{km}$

cruise, water samples were also incubated in duplicate opaque PC carboys at Stn 38; changes in bacterial abundance and production in transparent and opaque carboys were measured concomitantly. In the August cruise, carboy incubation and anchored sampling were conducted concurrently (Table 1). For anchored sampling, water samples were collected by hydrocast every 3 to $4 \mathrm{~h}$ at $0.5 \mathrm{~m}$ depth below the sea surface.

Light manipulation experiments. These 3 experiments were conducted in May and August 1996. Water samples from the reserved carboy were assigned to 6 duplicate 1.0 I PC bottles. These bottles were then put into acrylic holders covered with neutral density filters (LEE filters), which reduced the amount of incident light by $100,88,66,44,22$ and $0 \%$. Samples were preincubated 4 to $6 \mathrm{~h}$ in a specially made opaque tank with an artificial light source located at the center. The temperature inside the tank was maintained by running surface seawater. The 4 to $6 \mathrm{~h}$ period of pre-incu-

Table 1. List of physical and chemical conditions and ranges of bacterial properties of the diel studies. T: temperature; PAR: averaged daylight intensity; $\mathrm{Chl}$ a: initial chlorophyll a concentrations: TdR incorp.: thymidine incorporation rates. TC, OC: transparent and opaque carboy incubations

\begin{tabular}{|c|c|c|c|c|c|c|c|}
\hline $\begin{array}{l}\text { Date } \\
1996\end{array}$ & Stn & $\begin{array}{c}\mathrm{T} \\
\left({ }^{\circ} \mathrm{C}\right)\end{array}$ & $\begin{array}{c}\text { PAP } \\
\left(\mu \text { Einst } m^{-2} s^{-1}\right)\end{array}$ & $\begin{array}{c}\text { Chl } \mathrm{a} \\
\left(\mathrm{mg} \mathrm{m}^{-3}\right)\end{array}$ & $\begin{array}{l}\mathrm{PO}_{4}^{-3} \\
(\mu \mathrm{M})\end{array}$ & $\begin{array}{c}\text { Celi no. } \\
\left.\left(\times 10^{8} \text { cells }\right)^{-1}\right)\end{array}$ & $\begin{array}{l}\text { TdP incorp. } \\
\left(\mathrm{pM} \mathrm{h}^{-1}\right)\end{array}$ \\
\hline \multirow[t]{2}{*}{ May } & $38 . \mathrm{TC}$ & 24 & 810 & 0.14 & 0.04 & $4.75-5.36$ & $1.92-6.82$ \\
\hline & $38-\mathrm{OC}$ & 24 & - & - & - & $4.73-5.23$ & $1.08-2.70$ \\
\hline May & $22-\mathrm{TC}$ & 24 & 1500 & 0.26 & 0.09 & $7.25-7.66$ & $6.34-13.19$ \\
\hline Jul & $34-\mathrm{TC}$ & 30 & 1950 & 0.11 & 0.05 & $5.48-6.05$ & $1.48-7.73$ \\
\hline \multirow[t]{2}{*}{ Aug } & $34-\mathrm{TC}$ & 30 & 1910 & 0.15 & 0.06 & $6.23-6.89$ & $2.79-1.2 .36$ \\
\hline & 34-Anchored & 30 & - & - & - & $6.15-6.88$ & $2.79-12.50$ \\
\hline
\end{tabular}


bation was for the acclimation of phytoplankton activity when subjected to sudden light change. Bacterial and primary production of these 6 treatments were then measured immediately after pre-incubation.

Nutrient enrichment experiments. These 2 experiments were conducted on the July and August cruises Water samples collected from the reserved carboy were assigned to 4 treatments that were incubated in duplicate $1.01 \mathrm{PC}$ bottles at ambient temperature for $6 \mathrm{~h}$. Samples collected at noon and midnight were incubated under artificial and dark conditions, respectively. Average daylight intensity for these 2 noon experiments was about $1900 \mu$ Einst $\mathrm{m}^{-2} \mathrm{~s}^{-1}$ (Table 1). Treatments included (1) unamended control; (2) glucose addition; (3) $\mathrm{NH}_{4}{ }^{+}$plus $\mathrm{PO}_{4}{ }^{-3}$ addition ( $\mathrm{N}+\mathrm{P}$ treatment); and (4) glucose plus $\mathrm{NH}_{4}{ }^{+}$plus $\mathrm{PO}_{4}^{-3}$ addition ( $\mathrm{C}+\mathrm{N}+\mathrm{P}$ treatment). The final concentrations of glucose, $\mathrm{NH}_{4}{ }^{+}$and $\mathrm{PO}_{4}{ }^{-3}$ were $20,1.0$ and $1.0 \mu \mathrm{M}$, respectively. The $\mathrm{C}+\mathrm{N}+\mathrm{P}$ treatment was not performed on the July cruise.

Bacterial abundance and production. Bacterial abundance was determined by using the Acridine Orange Direct Count method (Hobbie et al. 1977). Samples fixed with glutaraldehyde (final conc., $1 \%$ ) were stained with acridine orange (final conc., $0.01 \%$ ) for $2 \mathrm{~min}$ and then filtered through $0.2 \mu \mathrm{m}$ polycarbonate filters prestained with Irgalan black solution. Slides were enumerated by epifluorescence microscopy (ZEISS, Axioplan). Bacterial production was estimated by ${ }^{3} \mathrm{H}$-thymidine (Fuhrman \& Azam 1982) incorporation. Triplicate or duplicate 30 to $40 \mathrm{ml}$ aliquots of water samples were incubated with ${ }^{3} \mathrm{H}$ [methyl]-thymidine (specific activity

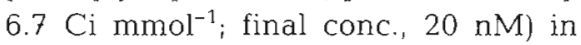
transparent $\mathrm{PC}$ tubes at in situ conditions for 2 to $3 \mathrm{~h}$. The formaldehyde (final conc., $1 \%$ ) killed samples, including time zero controls, were filtered through $0.2 \mu \mathrm{m}$ cellulose nitrate filters. Filters were rinsed 3 times each with ice cold $5 \%$ trichloroacetic acid and ice cold $80 \%$ ethyl alcohol sequentially. Scintillation cocktail $(6 \mathrm{ml}$; Ultima Gold, Packard) was added after dried filters were dissolved completely in $0.5 \mathrm{ml}$ of ethyl acetate. The radioactivity in the vials was determined by liquid scintillation (Packard 1600).

Primary production. Primary production was measured by the ${ }^{14} \mathrm{C}$ assimilation method (Parsons et al. 1984). In brief, 2 light and 1 dark $250 \mathrm{ml}$ clean $\mathrm{PC}$ bottles were filled with water sam- ples. After inoculation with $\mathrm{H}^{14} \mathrm{CO}_{3}^{-}$(final conc., $10 \mu \mathrm{Ci}$ $\mathrm{ml}^{-1}$ ), samples were incubated for 3 to $4 \mathrm{~h}$ at in situ light intensity and cooled with running seawater. Following retrieval, the water samples were immediately filtered through Whatman $25 \mathrm{~mm} \mathrm{GF/F} \mathrm{filters} \mathrm{under}$ low light and low pumping pressure $(<100 \mathrm{~mm} \mathrm{Hg}$ ). The filters were then placed in scintillation vials, and $0.5 \mathrm{ml}$ of $0.5 \mathrm{~N} \mathrm{HCl}$ was added to remove residual $\mathrm{H}^{14} \mathrm{CO}_{3}^{-}$. Radioactivity was counted in a liquid scintillation counter (Packard 1600) after the addition of $10 \mathrm{ml}$ scintillation cocktail (Ultima Gold, Packard) into the vials.

\section{RESULTS}

\section{Diel studies}

Bacterial abundance did not vary much over the diel cycle; the difference between abundance maximum and minimum within each study never exceeded $13 \%$ (Table 1). The cell counts in transparent and opaque carboys at Stn 38 were very similar and, in fact, at any sampling point, the difference between these 2 incubations did not exceed $10 \%$ (Fig. $2 \mathrm{~A}$ ). In contrast, the
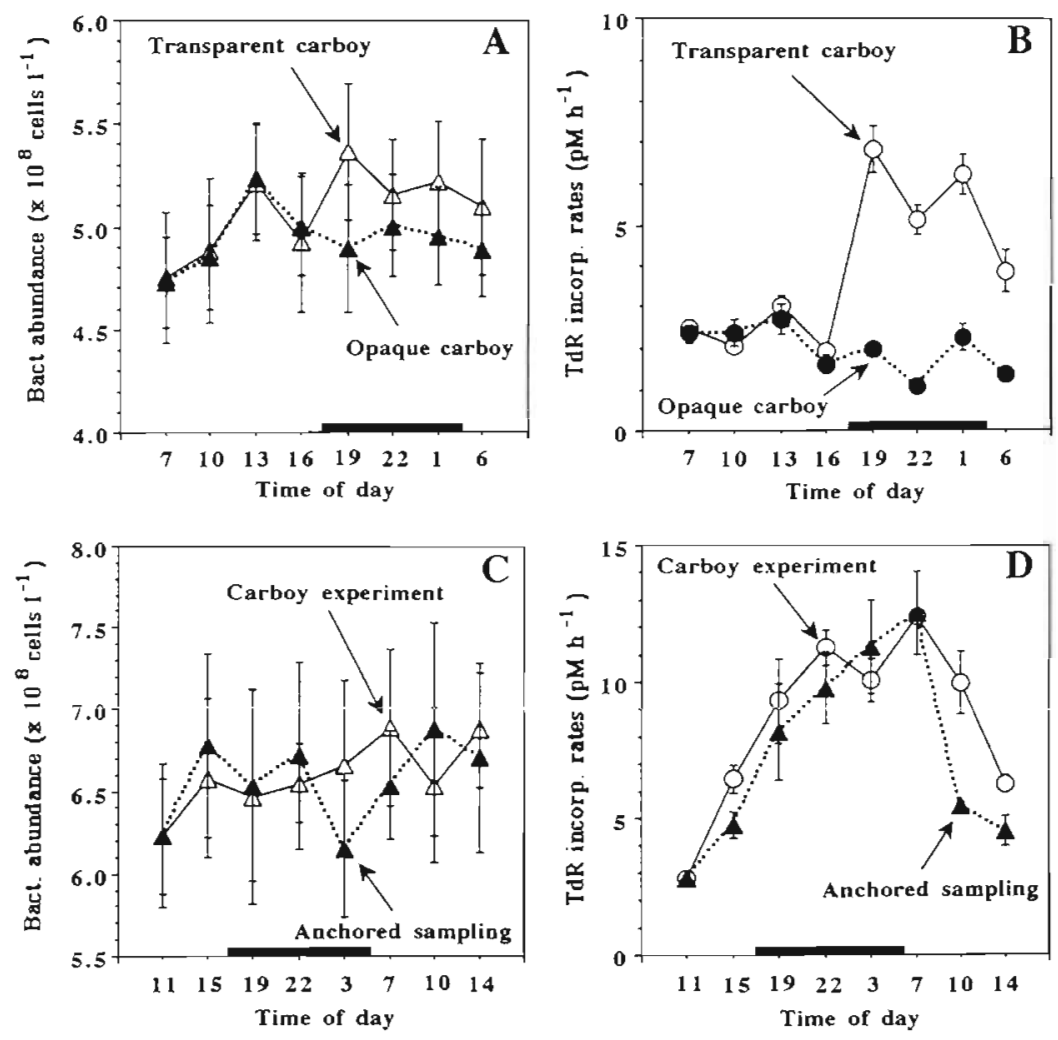

Fig. 2. Diel changes of bacterial abundance and thymidine (TdR) incorporation rates at (A, B) Stns 38-May and (C, D) 34-August. Vertical bars represent standard deviation and thick bars indicate night-time 
bacterial thymidine ( $\mathrm{TdR}$ ) incorporation rates in transparent carboys varied more than 3 -fold with higher values (>5.0 $\mathrm{pM} \mathrm{h}^{-1}$ ) appearing during night-time (Fig. 2B). Values of the TdR incorporation in transparent and opaque carboys were similar for the first 4 sampling points. After that, the TdR incorporation of opaque carboys still remained low $\left(<2.2 \mathrm{pM} \mathrm{h}^{-1}\right)$ and were only $<40 \%$ of those of transparent carboys. In the August experiments, bacterial abundance in carboy incubation and anchored sampling were quite similar to each other, with neither showing any diel change (Fig. 2C). Nevertheless, the TdR incorporation in both experiments showed a strong diel signal with higher values appearing during night-time (Fig. 2D). Bacterial abundance and the TdR incorporation recorded at Stns 22 and 34 (the July one) followed the same patterns
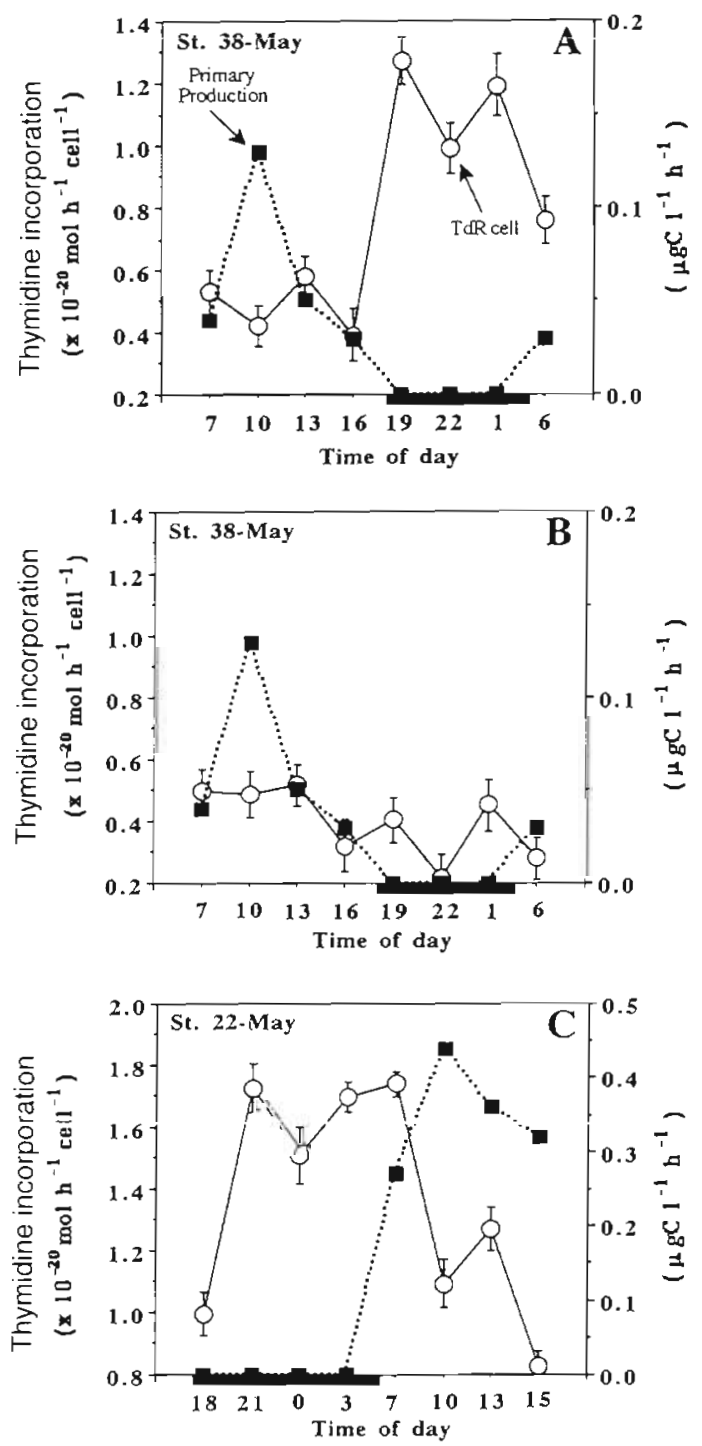

described above (Table 1); cell counts did not change significantly over the diel cycle but the values of the $\mathrm{TdR}$ incorporation recorded in night-time were at least $2 \times$ higher than those in day-time.

Fig. 3A-F depicts changes of bacterial thymidine incorporation rates on a per cell basis (TdR cell-1 0.22 to $1.91 \times 10^{-20} \mathrm{~mol} \mathrm{~h}^{-1} \mathrm{cell}^{-1}$ ) and primary production (PP; 0.03 to $0.66 \mu \mathrm{g} \mathrm{C} \mathrm{l}^{-1} \mathrm{~h}^{-1}$ ) for the 4 diel studies. Overall, the $\mathrm{TdR}$ cell $^{-1}$ showed a negative trend with $P P$ in all studies. Night-time TdR cell ${ }^{-1}$ were about 2 - to 4 -fold of those recorded during day-time. At Stn 38, the TdR cell $^{-1}$ in transparent (Fig. 3A) and opaque (Fig. 3B) carboys were similar for the first 4 sampling points (daytime, 0.4 to $0.5 \times 10^{-20} \mathrm{~mol} \mathrm{~h}^{-1}$ cell $^{-1}$ ). After that, the TdR cell ${ }^{-1}$ in transparent carboys increased about 3 fold $\left(>1.0 \times 10^{-20} \mathrm{~mol} \mathrm{~h}^{-1}\right.$ cell $\left.^{-1}\right)$, while those of opaque
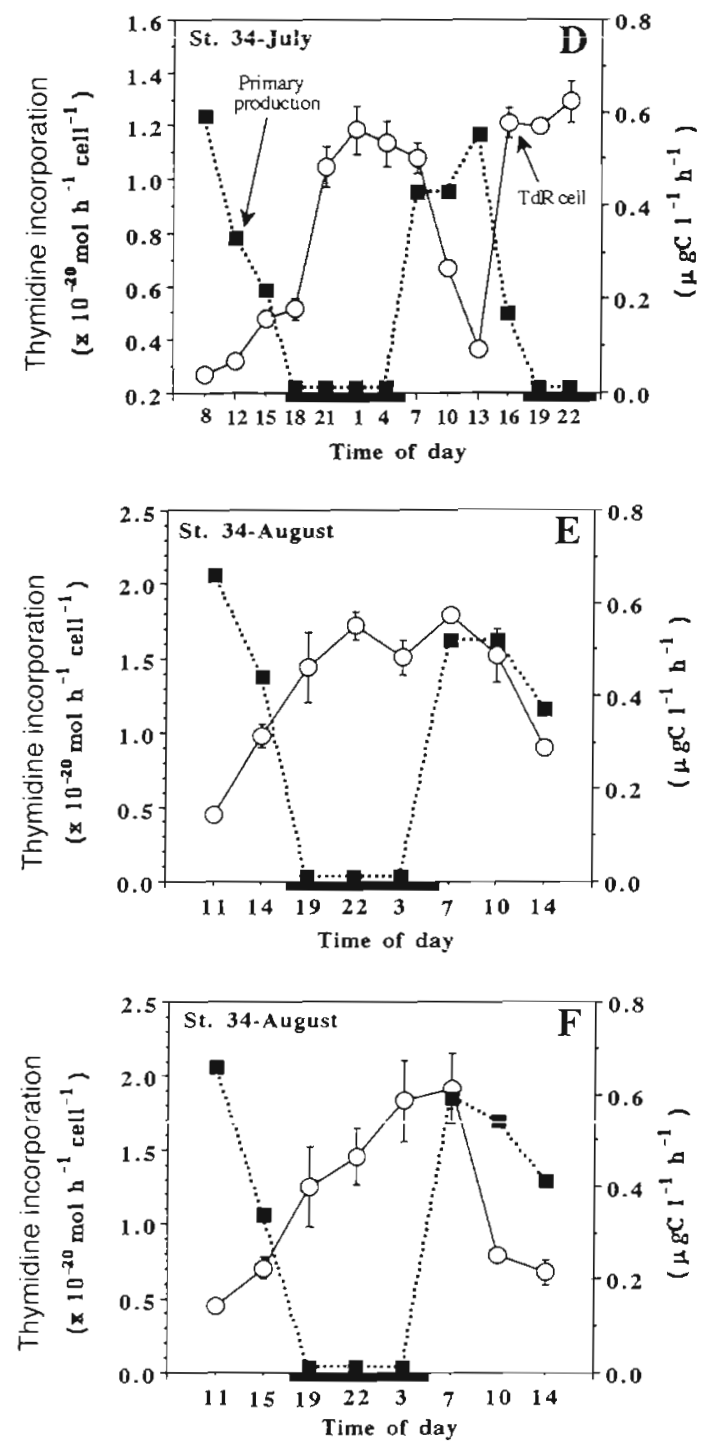

Fig. 3. Diel changes of bacterial thymidine incorporation rate per cell. (O) left axis) and primary production ( $\mathbf{\square}_{i}$ right axis) at the 4 sampling stations. (B) Opaque carboy; (F) anchored sampling 

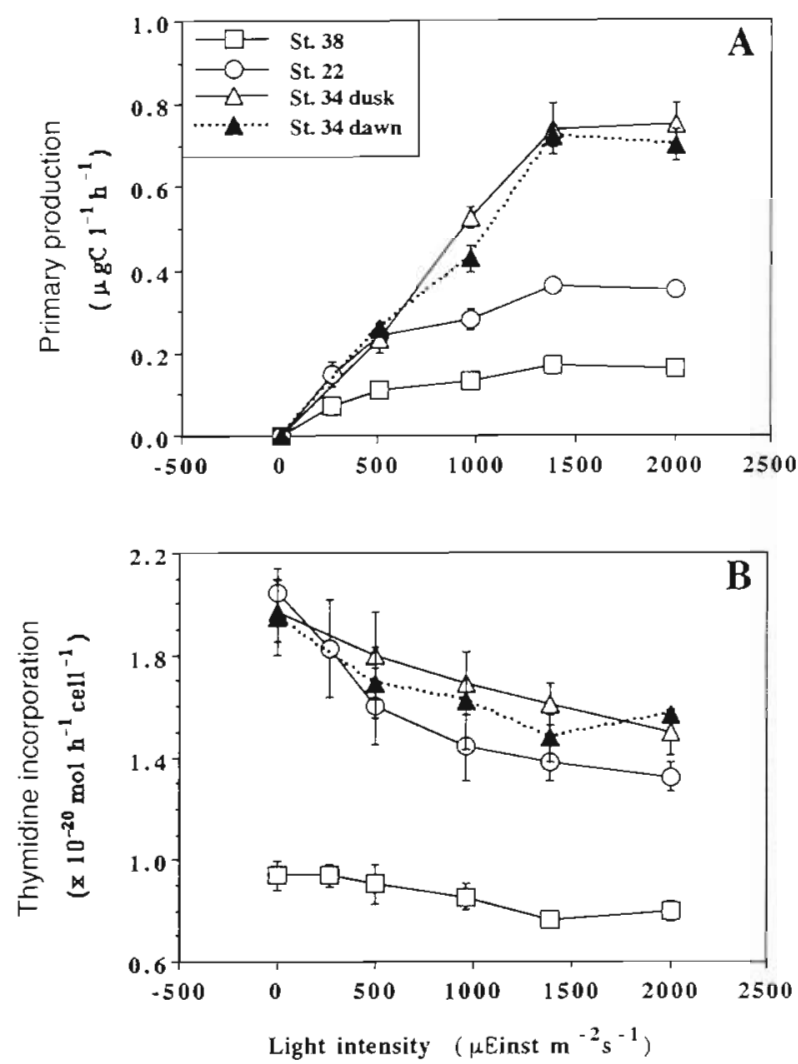

Fig. 4. (A) Light responses of primary production and (B) bacterial thymidine incorporation rate per cell in light manipulation experiments

carboys still remained low with values ranging from 0.21 to $0.45 \times 10^{20} \mathrm{~mol} \mathrm{~h}^{-1}$ cell $^{-1}$. On the August cruise (Fig. 3E,F), the TdR cell ${ }^{-1}$ derived from carboy incubation and anchored sampling revealed a similar pattern, with higher values appearing at night-time.

\section{Light manipulation experiments}

Within each experiment, bacterial abundance did not change during the incubation periods, and cell counts were quite similar among treatments (data not shown). Values of PP increased with light intensity and saturated at $1380 \mu$ Einst $\mathrm{m}^{-2} \mathrm{~s}^{-1}$ (Fig. 4A). The $\mathrm{TdR}$ cell ${ }^{-1}$ showed a negative trend with light intensity (Fig. 4B) and PP (Table 2). Some variations were noted among experiments; the slope of the $\mathrm{TdR}$ cell ${ }^{-1}$ (dependent variable) on PP of Stn $22(-2.03 \pm 0.17)$ was about 2 and $4 \times$ of those of Stns 38 and 34, respectively (Table 2). However, the slopes of the dusk and dawn experiments performed at Stn 34 were almost exactly the same. We note also that for each experiment, the variations of PP and TdR cell ${ }^{-1}$ under an artificial light source were very similar to those observed in diel studies (Fig. 4A-D). For example, on the August cruise, the difference between the PP maxima of the light manipulation experiments ( 0.70 to $0.75 \mu \mathrm{g} \mathrm{C} \mathrm{l}^{-1} \mathrm{~h}^{-1}$; Fig. 4A) and those of carboy incubation and anchored samplings $\left(0.67 \mu \mathrm{g} \mathrm{Cl}^{-1} \mathrm{~h}^{-1}\right.$; Fig. 3E,F) was only 4.5 to $12 \%$; meanwhile, the values of the $\mathrm{TdR}$ cell $^{-1}$ recorded under artificial light (0.91 to $1.97 \times 10^{-20} \mathrm{~mol} \mathrm{~h}^{-1}$ cell $^{-1}$; Fig. 4B) were within the range of the latter 2 experiments $(0.45$ to $1.70 \times 10^{-20} \mathrm{~mol} \mathrm{~h}^{-1}$ cell $^{-1}$; Fig. 3E,F) which were conducted in sunlight.

\section{Nutrient addition experiments}

Within each experiment, cell counts were quite similar among treatments and did not change during the incubation periods (data not shown). However, for those treatments in which nutrient additions affected the $\mathrm{TdR} \mathrm{cell}^{-1}$ (see below), the cells were larger in size than those in the control (visual estimation). For the July experiment (Fig. 5), the TdR cell-1 of noon samples were not affected by the addition of organic carbon or inorganic nutrients, and the TdR cell-1 of the 3 treatments $\left(0.46\right.$ to $0.56 \times 10^{-20} \mathrm{~mol} \mathrm{~h} \mathrm{~h}^{-1}$ cell $\left.{ }^{-1}\right)$ were low and did not differ from each other. In midnight samples, the $\mathrm{TdR}$ cell $^{-1}$ of glucose treatment $\left(2.35 \pm 0.26 \times 10^{-20} \mathrm{~mol}\right.$ $\mathrm{h}^{-1}$ cell $^{-1}$ ) was not significantly different from that in the control $\left(2.55 \pm 0.18 \times 10^{-20} \mathrm{~mol} \mathrm{~h}^{-1}\right.$ cell $\left.^{-1} ; \mathrm{p}>0.05\right)$, but in contrast, the $\mathrm{TdR}$ cell ${ }^{-1}$ of $\mathrm{N}+\mathrm{P}$ treatment (3.86 \pm $0.38 \times 10^{-20} \mathrm{~mol} \mathrm{~h}^{-1} \mathrm{cell}^{-1}$ ) was about $50 \%$ higher than that in the control $(p>0.01)$. Results of the August experiments were almost exactly the same as those of

Table 2. Correlation coefficients and slopes of linear regression among measured variables in light manipulation experiments. All were significant at $p<0.01 .+,-$ : positive and negative correlation, respectively; SD: standard deviation; na: not analyzed; I: light intensity ( $\mu$ Einst $\mathrm{m}^{-2} \mathrm{~s}^{-1}$ ) PP: primary production; $\mathrm{TdR}$ cell $^{-1}$; thymidine incorporation rate per cell

\begin{tabular}{|c|c|c|c|c|}
\hline Stn & & $\begin{array}{c}P P \\
\left(\mu g\left(L^{-1} h^{-i}\right)\right.\end{array}$ & $\begin{array}{c}\text { TdR cell } \\
\left(10^{-20} \mathrm{~mol} \mathrm{~h}^{-1} \mathrm{cell}^{-1}\right)\end{array}$ & $\begin{array}{l}\text { Slope } \pm \text { SD of } \\
\text { TdR cell }{ }^{-1} \text { on } \mathrm{PP}\end{array}$ \\
\hline \multirow[t]{2}{*}{38} & 1 & +0.87 & -0.89 & \\
\hline & PP & na & -0.88 & $-1.02 \pm 0.28$ \\
\hline \multirow[t]{2}{*}{22} & I & +0.88 & -0.90 & \\
\hline & PP & na & -0.98 & $-2.03 \pm 0.27$ \\
\hline \multirow[t]{2}{*}{ 34-dusk } & I & +0.95 & -0.99 & \\
\hline & $\mathrm{PP}$ & na & -0.97 & $-0.54 \pm 0.07$ \\
\hline \multirow[t]{2}{*}{ 34-dawn } & I & +0.95 & -0.86 & \\
\hline & PP & na & -0.95 & $-0.56 \pm 0.11$ \\
\hline
\end{tabular}




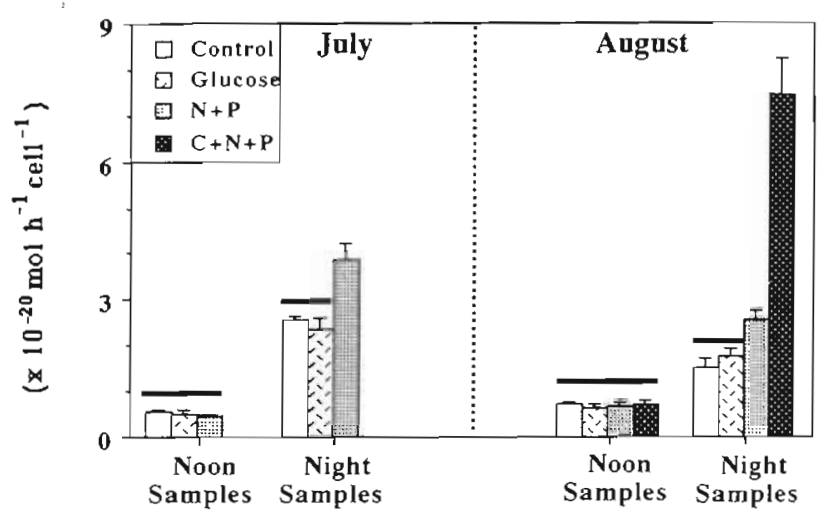

Fig. 5. Nutrient enrichment effects on bacterial thymidine incorporation rate per cell. Note the $\mathrm{C}+\mathrm{N}+\mathrm{P}$ treatment was not performed in the July experiments. Horizontal bars indicate no difference in mean values at $\mathrm{p}=0.05$ level

July. The individual means of the 4 noon treatments ( 0.65 to $0.70 \times 10^{-20} \mathrm{~mol} \mathrm{~h}^{-1}$ cell $^{-1}$ ) were low and showed no difference from each other $(\mathrm{p}>0.05)$. The TdR cell ${ }^{-1}$ of $\mathrm{N}+\mathrm{P}\left(2.56 \pm 0.21 \times 10^{-20} \mathrm{~mol} \mathrm{~h}^{-1} \mathrm{cell}^{-1}\right)$ and $\mathrm{C}+\mathrm{N}+\mathrm{P}$ treatments $\left(7.41 \pm 0.78 \times 10^{-20} \mathrm{~mol} \mathrm{~h}^{-1} \mathrm{cell}^{-1}\right)$ of night samples were 68 and $387 \%$ higher than those in the control, respectively. The addition of glucose alone $\left(1.77 \pm 0.15 \times 10^{-20} \mathrm{~mol} \mathrm{~h}^{-1} \mathrm{cell}^{-1}\right)$ had no effect on the TdR cell ${ }^{-1}$

\section{DISCUSSION AND CONCLUSIONS}

As suggested by Fuhrman et al. (1985), the use of large volume carboys to investigate biological interactions has both advantages and disadvantages. In terms of benefits, physical disturbances, such as tidal effects and the mixing of different water masses, can be prevented so that investigation into the interactions among biological and chemical components can be performed under more homogeneous conditions. On the other hand, the growth of bacteria and other planktonic organisms in carboys might be different from those in the field (bottle or containment effects).

Several lines of evidence suggested that the results from carboy observations and light manipulation experiments might still be suitable to infer phenomena actually occurring in the field. The values of the TdR cell $^{-1}$ and PP derived from carboy incubation and anchored sampling were basically in good agreement (Fig. 3E,F). Both the trends and values of the TdR cell-1 (as well as PP) were similar during the first and the second incubation day (Fig. 3D). Under artificial light conditions, the value of the maximal PP in each manipulation experiment was still similar to that of its parallel carboy study; at Stns 38, 22 and 34, maximal PP were $0.17 \pm 0.01,0.36 \pm 0.02$ and $0.72 \pm 0.03 \mu \mathrm{g} \mathrm{C}^{-1} \mathrm{~h}^{-1}$, respectively (Fig. 4A,B); their parallel carboy values were $0.13 \pm 0.01,0.44 \pm 0.02$ and $0.66 \pm 0.03 \mu \mathrm{g} \mathrm{Cl}^{-1}$ $\mathrm{h}^{-1}$, respectively (Fig. $3 \mathrm{~A}-\mathrm{F}$ ).

The bacterial diel pattern of this study is opposite to that reported by Fuhrman et al. (1985) which showed a close coupling between bacterial growth and primary production in the southern California Bight. Such discrepancy is interesting but not easy to explain. System conditions and experimental methods are quite distinct in these 2 studies. For examples, the data of Fuhrman et al. (1985) were derived from free-floating drogues deployed at depths of 10 to $20 \mathrm{~m}$, where much of the surface light intensity was attenuated, whereas the data of this study were obtained from on deck carboy incubation under full surface light intensity. Maximal

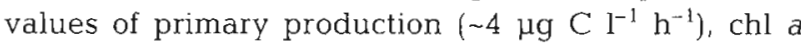

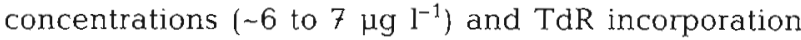
rates $\left(-15 \mathrm{pM} \mathrm{h}^{-1}\right)$ measured in their drogue study are at least 2 -fold higher than those of this study (Table 1 , Fig. 3A-F). These indicate that the southern California Bight is probably 'much less' oligotrophic than the Kuroshio water. No satisfactory explanation can be offered at present, except to point out these contrarieties.

It is worth noting that PAR cannot directly affect bacterial growth since heterotrophic bacteria do not have photo-pigments; the variance of bacterial growth might be due to the change of photosynthetic performance which is a direct function of PAR. In the opaque carboy (Fig. 3A), night-time TdR cell ${ }^{-1}$ did not increase when PAR was cut off, suggesting that the photosynthetic product (EDOC) produced during day-time could be important in supporting bacterial growth at night-time in oligotrophic environments.

It is not clear why the slopes of PP on the TdR cell ${ }^{-1}$ varied among experiments (Table 2). The bacterial populations in the surface water samples taken from different locations and in different months (except Stn 34, see below) might have been different (Lee \& Fuhrman 1990), which could have resulted in distinct slope values. Evidence for this came from the similar slope values derived from the dawn $(-0.54 \pm 0.07)$ and dusk $(-0.56 \pm 0.11)$ experiments performed at Stn 34 . There, water samples were taken from the same carboy only at 1 night interrals, which means that the pos sibility of using the same bacterial (and phytoplankton) populations in these 2 experiments should have been high.

This study demonstrates that, in the surface ocean, UV radiation is not required for bacterial diel variation since UV was excluded in the experimental set-up. Penetration of UV-B (280 to $320 \mathrm{~nm}$ ) radiation through the PC carboy was examined by a UV sensor (UV$160 \mathrm{~A}_{\text {; }}$ Shimadzu) in the laboratory; less than $5 \%$ of the UV-B penetrated through the PC carboys (data not 
shown). The emission spectrum of the artificial light source was measured by a spectroradiometer (LI-1800, Licor) which indicated extremely low UV-A (320 to 400 $\mathrm{nm}$ ) and UV-B radiation; emitted UV-A and UV-B could be further absorbed by $1.0 \mathrm{l}$ PC bottles and the acrylic holders (data not shown).

To avoid interference from UV, all of the diel studies, except for the one in August (Fig. 3E,F), were started after dusk or before dawn. In these carboy experiments, the diel patterns of the bacterial rate parameters were significant and consistent over different study sites and months. In light manipulation experiments, whole water samples were incubated under a condition free of UV-B; both bacteria and phytoplankton changed their activities significantly with different light (PAR) intensities (Fig. 4A,B). UV-A can also inhibit bacterial activity (Herndl et al. 1997) although its damaging effect is about 10 to $20 \%$ of that of UV-B (Herndl et al. 1993; their Fig. 2). In the diel studies, the PC carboy removed about $50 \%$ of UV-A (data not shown). Therefore, the possible UV-A inhibition on $\mathrm{TdR}$ cell $^{-1}$ is about 5 to $10 \%$, which is not satisfactory in explaining the 2 to $4 \times$ change of TdR cell ${ }^{-1}$ observed in the carboy experiments (Fig. 3A-F). Yet, the observed diel pattern might have been different under UV exposure.

Top-down control processes (bacterivory) can affect bacterial diel cycles and their utilization of different nitrogen sources. Wikner et al. (1990) showed that in several coastal and ocean environments, microflagellate grazing rates on bacteria were much higher during the day-time. Gonzalez et al. (1990), del Giorgio et al. (1996) and others suggested that bacteriovores might selectively prey on fast growing bacteria. One may deduce that during the day-time, there are probably more inactive bacteria with less capacity of utilizing EDOC and competing for DIN (dissolved inorganic nutrient) with algae. Concurrently, higher flagellate activities during the day-time may result in higher dissolved organic matter (DOM) release or excretion rates (Nagata \& Kirchman 1992); this may lead bacteria to utilize DOM for growth and leave DIN for algae. In addition, when DOM is in surplus, bacteria may act as decomposers instead of DIN assimilators (Goldman \& Dennett 1991 and citations therein).

The study of bacterial diel cycles could be important for constraining hypotheses on environmental regulation of bacterial growth, temporal variation in carbon flux pathways, field sampling strategy as well as methodology of bacterial production measurement.

In the open ocean, the low availability of dissolved inorganic nutrients (DIN; $\mathrm{NH}_{4}{ }^{+}$and $\mathrm{PO}_{4}^{-3}$ ) in surface waters may limit the growth of bacteria and phytoplankton concomitantly; bacteria are superior to phytoplankton in competing for DIN due to their larger sur- face to volume ratio (Bratbak \& Thingstad 1985). In marine systems, bacteria are responsible for perhaps $30 \%$ or even $50 \%$ of the total uptake of ambient DIN (see Fuhrman 1992, Kirchman et al. 1994). However, as noted by Fuhrman (1992), such uptake does not necessarily occur all the time. This has led to some speculation that the competitive advantages for DIN between bacteria and phytoplankton might vary with other environmental factors, such as the fluctuation of PAR.

The results of nutrient enrichment experiments (Fig. 4) imply that bacteria cannot mobilize dissolved organic carbon (glucose) for growth under conditions when DIN is deficient. This has been well documented by several studies (Obernosterer \& Herndl 1995, Pomeroy et al. 1995, Shiah et al. 1997). This study further suggests that inorganic nutrient effects on bacterial growth seem to be light (PAR)-dependent, or to be related to some other planktonic processes which oscillate diurnally.

The routine method for measuring bacterial production is to spike samples with ${ }^{3} \mathrm{H}$-TdR (or ${ }^{3} \mathrm{H}$-Leu) and incubate them in the dark at in situ temperature for 2 to $3 \mathrm{~h}$. It is not known how fast bacterial rate parameters respond to the change of light (PAR) intensity. If these processes occur within hours (i.e. shorter than incubation time), then it is necessary to control light intensity during incubation, especially for samples taken during day-time.

In the surface waters of the oligotrophic ocean, bacteria show an obvious diel cycle with higher production and growth at night. This finding is different from many previous studies showing that the diel cycles of phytoplankton and bacteria are closely coupled. The present study demonstrates that UV radiation is not required for giving rise to such a phenomenon. The departure of the diel patterns between bacteria and phytoplankton as well as the differential nutrient enrichment effects on bacterial growth under full-light and dark conditions imply that, within the microbial loop, the physical (PAR, UV radiation), chemical (DIN, DOM supply rates) and biological (bacterivory) processes may interactively affect their components' behavior. It is well known that microbial loop processes play an important role in transforming DOM in the open ocean, bacterial diel activity patterns might eventually affect the strength of microbial food web pathways during day-time and night-time. The actual mechanisms behind these phenomena are important but need more experimental data for a better understanding.

Acknowledgements. CORE-NSC contribution paper number 1. Support for this research and F.-K.S. was provided by the NSC, Taiwan, ROC. I thank Dr K.-K. Liu for his encouragement and comments on writing this manuscript, Dr G.-C. Gong for providing chlorophyll $a$ and phosphate data and $\mathrm{Mr}$ 
M. C. Tsai for graphic preparation. Valuable comments from Dr F. Azam and 3 anonymous reviewers are greatly appreciated. Cruise assistance from the officers and crew of RV 'Ocean researcher I' is also deeply appreciated.

\section{LITERATURE CITED}

Bratbak G. Thingstad TF (1985) Phytoplankton-bacteria interactions: an apparent paradox? Analysis of a model system with both competition and commensalism. Mar Ecol Prog Ser 25:23-30

Coffin RB, Connolly JP, Harris PS (1993) Availability of dissolved organic carbon to bacterioplankton examined by oxygen utilization. Mar Ecol Prog Ser 101:9-22

Cotner JB, Ammerman JW, Peele ER, Bentzen E (1997) Phosphorus-limited bacterioplankton growth in the Sargasso Sea. Aquat Microb Ecol 13(2):141-149

del Giorgio PA, Gasol JM, Vaqué D, Mura P, Aqusti S, Duarte CM (1996) Bacterioplankton community structure: protists control net production and the proportion of active bacteria in a coastal marine community. Limnol Oceanogr 41 (6): $1169-1179$

Ducklow HW, Carlson CA (1992) Oceanic bacterial production. In: Marshall $\mathrm{KC}$ (ed) Advance in microbial ecology. Plenum, New York, p 113-181

Fuhrman JA (1992) Bacterioplankton roles in cycling of organic matter: the microbial food web. In: Falkowski PG, Woodhead AD (eds) Primary productivity and biogeochemical cycles in the sea. Plenum, New York, p 361-383

Fuhrman JA, Azam F (1982) Thymidine incorporation as a measurement of heterotrophic bacterioplankton production in marine surface waters: evaluation and field results. Mar Biol 66:109-120

Fuhrman JA, Eppley RW, Hagström A, Azam F (1985) Diel variations in bacterioplankton, phytoplankton, and related parameters in the Southern California Bight. Mar Ecol Prog Ser 27:9-20

Goldman JC, Dennett MR (1991) Ammonium regeneration and carbon utilization by marine bacteria grown on mixed substrates. Mar Biol 109:369-378

Gonzalez JM, Sherr EB, Sherr BF (1990) Size-selective grazing on bacteria by natural assemblages of estuarine

Editorial responsibility: Faroog Azam,

La Jolla, California, USA flagellates and ciliates. Appl Environ Microbiol 56(3): $583-589$

Herndl GJ, Muller-Niklas G. Frick J (1993) Major role of ultraviolet- $B$ in controlling bacterioplankton growth in the surface layer of the ocean. Nature 361:717-719

Herndl GJ, Brugger A, Hager S, Kaiser E, Obernosterer I, Reitner B, Slezak D (1997) Role of ultraviolet-B radiation on bacterioplankton and the availability of dissolved organic carbon. Plant Ecol 128:42-51

Hobbie JE, Daley RJ, Jasper S (1977) Use of nuclepore filters for counting bacteria by fluorescence microscopy. Appl Environ Microbiol 33(5):1225-1228

Jeffrey $W H$, Pledger RJ, Aas $P$, Hager $S$, Coffin RB, Haven RV, Mitchell DL (1996) Diel and depth profiles of DNA photodamage in bacterioplankton exposed to ambient solar ultraviolet radiation. Mar Ecol Prog Ser 137. $283-291$

Kirchman DL, Ducklow HW, McCarthy JJ, Garside C (1994) Biomass and nitrogen uptake by heterotrophic baclerid during the spring phytoplankton bloom in the North Atlantic ocean. Deep-Sea Res 41 (5/6):879-895

Lee S, Fuhrman JA (1990) DNA hybridization to compare species compositions of natural bacterioplankton assemblages. Appl Environ Microbiol 56(3):739-746

Nagata T, Kirchman DL (1992) Release of dissolved organic matter by heterotrophic protozoa: implications for microbial foodwebs. Arch Hydrobiol 35:99-109

Obernosterer I, Herndl GJ (1995) Phytoplankton extracellular release and bacterial growth: dependence on the inorganic N:P ratio. Mar Ecol Prog Ser 116:247-257

Parsons TR, Maita Y, Lalli CM (1984) A manual of chemical and biological methods for seawater analysis. Pergamon, New York

Pomeroy LR, Sheldon JE, Sheldon WMS Jr, Peters F (1.995) Limits to growth and respiration of bacterioplankton in the Gulf of Mexico. Mar Ecol Prog Ser 117:259-268

Shiah FK, Kao SJ, Liu KK (1998) Bacterial production in the western equatorial Pacific: implications of inorganic nutrient effects on dissolved organic carbon accumulation and consumption. Bull Mar Sci 62(3):795-808

Wikner J, Rassoulzadegan F, Hagströrn A (1990) Periodic bacterivore activity balances bacterial growth in the marine environment. Limnol Oceanogr 35(2):313-324

Submitted: May 23, 1997; Accepted: August 31, 1998

Proofs received from author(s): June 4, 1999 